\title{
Climate change and evolution of landslide hazard at Nefyn Bay, North Wales.
}

\author{
G.O. Jenkins \& A.D. Gibson \\ British Geological Survey, Nottingham, England, United Kingdom
}

A. J. Humpage

British Geological Survey, Cardiff, Wales, United Kingdom

\begin{abstract}
An essential tool in the management of present slope instability is understanding the climatic history of an area, and how this relates to the deposition and stability of sediments. Late Pleistocene and early Holocene climatic changes have had a significant influence upon sediment deposition and subsequent modification, and this has a direct bearing on Holocene coastal landsliding that continues to the present day. The cliffs of Nefyn Bay, on the northern coast of the Lleyn Peninsula in North Wales, exhibit a complicated succession of sediments deposited as result of changes in geoenvironmental conditions over time. Examination of the cliffs has shown that understanding the complex relationship between sediments, climate and slope stability is essential if we are to successfully manage unstable terrain in the region, given that the frequency of extreme climatic events is forecast to increase in the future.
\end{abstract}

\section{INTRODUCTION}

The superficial geology within Nefyn Bay, North Wales, is dominated by a complex sedimentary succession. This succession was deposited under variable geo-environmental conditions, associated with the decay of the Irish Sea Ice Sheet towards the end of the Devensian Ice Age. This environment, the deposits laid down by this environment, and alterations to the area by subsequent environmental changes have defined the nature and mechanisms of the landslide activity and hazard within Nefyn Bay today.

On $2^{\text {nd }}$ January 2001 a series of shallow landslides caused extensive disruption to an access road and car park located mid-cliff in the centre of the bay. One person was fatally injured and a second severely injured when a debris flow pushed their vehicle over the sea wall. Following this event, a programme of research, funded jointly by the British Geological Survey (BGS) and Gwynedd Council, was undertaken to investigate the incident and to assess the landslide hazards in Nefyn Bay. A full account of this hazard assessment was given by Gibson \& Humpage (2001a\&b). This paper discusses the impact of past and present climate change upon the North Wales coast.

\section{LOCATION}

Nefyn Bay is a northwest-facing bay on the north coast of the Lleyn Peninsula in North Wales (Fig. 1).
Two bedrock headlands enclose the bay - Penrhyn Bodeilas to the northeast and Penrhyn Nefyn to the southwest (Fig. 2).

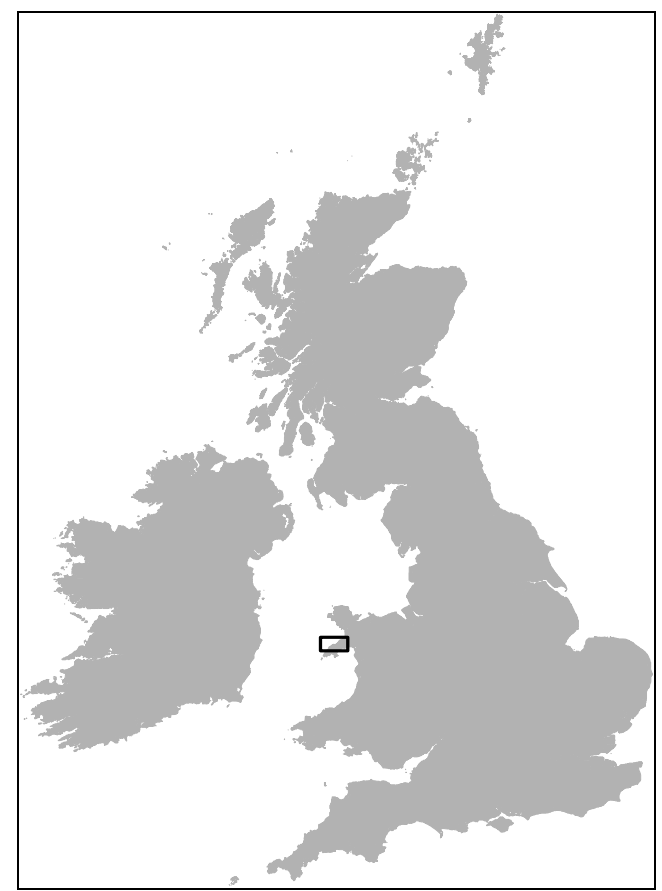

Figure 1. Location of Nefyn Bay, North Wales, United Kingdom. 


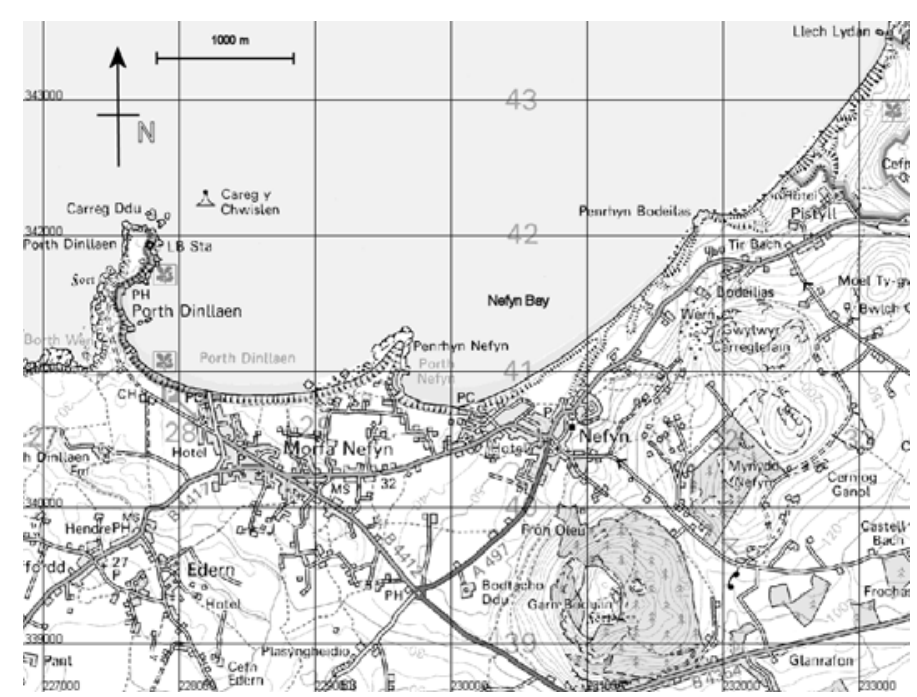

Figure 2. Location of Nefyn Bay, North Wales, United Kingdom. Ordnance Survey Topography (C) Crown Copyright. Licence Number: 100017897/2006.

\section{GEOLOGICAL BACKGROUND}

The area lies within the British Geological Survey 1:50,000 scale geological map sheet 118 (Nefyn). Bedrock is exposed only at the base of the cliffs on the headlands at each end of the bay (Fig. 3). At Penrhyn Bodeilas, bedrock is composed of a coarsegrained granite of unknown age, whereas the headland at Penrhyn Nefyn is composed of Precambrian metamorphosed granites and Ordovician shales. These metamorphic rocks are also believed to underlie the length of Nefyn Bay but are not exposed.

Superficial deposits exposed in the headlands at either end of the bay differ in character. At Penrhyn Bodeilas, the near vertical, $30 \mathrm{~m}$ high sea cliff is dominated by $15-20 \mathrm{~m}$ of glacial till, which is divided into a lower, structureless, lodgement till containing many clasts (including sandstone, mudstone and metamorphic fragments) ranging in size from gravel to large boulders $3 \mathrm{~m}$ in diameter; and an overlying, bedded flow till where clasts show some evidence of flow realignment. The till is overlain by 1-5 m of grey, stiff, laminated clays and soft, massive silts. Above the silt and clay unit, the sea cliffs are capped by 3-15 m of glacio-fluvial outwash deposits varying from gravel to sand and silt. In a few locations the glacio-fluvial deposits are overlain by Head deposits and yellow wind-blown fine silty sand probably of loessic origin.

At Penrhyn Nefyn, in the south west of the bay, the till forms only the lowest metre of the cliff. The remainder of the approximately $25 \mathrm{~m}$ high cliff is composed of glacio-fluvial outwash deposits which are predominantly well-bedded, fine- to mediumgrained sand and gravel, with individual beds up to $5 \mathrm{~m}$ in thickness.

The remainder of Nefyn Bay, between the two headlands, can be divided into two distinctive sedimentary suites. In the southern-central section of the bay, near Penrhyn Nefyn, the cliffs, up to $40 \mathrm{~m}$ in height, expose a variable succession of sediments. Rarely exposed at the base of the cliff is a grey, stiff till containing clasts of variable size and shape in a silt/clay matrix. This is overlain by fine to coarsegrained sand with lenses of gravel and isolated lenticular bodies of grey, stiff, laminated silt, up to $10 \mathrm{~m}$ in width above which is a persistent, uniform stratigraphy of an erosive based $2 \mathrm{~m}$ thick, calcium carbonate cemented, indurated cobble gravel overlain by up to $1 \mathrm{~m}$ of soft, grey, laminated clay. The upper third of the cliff in this section of the bay comprises a $1 \mathrm{~m}$ thick grey massive silt which grades upwards into a brown sandy silt and silty sand and gravel with lenses of grey-brown, loose sand and gravel.

Within this upper section of the cliff, are large, isolated sedimentary bodies composed predominantly of massive grey silt, within which are rare mudstone clasts up to $100 \mathrm{~mm}$ in size and lenticular beds of sand up to $1 \mathrm{~m}$ in thickness. The silt bodies appear to be located within basins up to $60 \mathrm{~m}$ in diameter and up to $25 \mathrm{~m}$ deep. At the top of the cliff, a thin (up to $0.5 \mathrm{~m}$ thick) deposit of yellowish brown silt occurs locally. Although not examined in detail, the open texture and uniform grain size indicates that it is likely to be wind-blown loess. Head deposits infilling channels or depressions a few metres deep in the surface topography were also recorded. These consist of fine-grained sediments and angular clasts up to $100 \mathrm{~mm}$ in diameter, which show some evidence of sorting and flow.

At the car park, site of the 2001 landslide, synsedimentary faulting has resulted in a relative increase in thickness of the succession above the cobble-gravel unit compared to elsewhere in this part of the bay. As a consequence, the upper half of the cliff has a different succession extending laterally approximately $200 \mathrm{~m}$. The upper sand and gravel unit is overlain by an additional grey laminated silt/clay bed, above which is a distinct, discontinuous and occasionally thick unit of stiff brown silt/clay (Bed 7c of Gibson \& Humpage, 2001a. Together these form a distinctive terrace within the cliff profile. The upper cliff at this location is dominated entirely by soft, loose, fine- to medium-grained, cross-bedded sand (Bed 7a of Gibson \& Humpage, 2001a).

In the northern-central region, near Penhryn Bodeilas, the sediments are composed of red-brown, well bedded, poorly to moderately sorted, glaciofluvial outwash sands and gravels, varying in size from fine-grained sand to coarse gravel. Although generally loose, there are isolated gravel-dominated beds cemented by calcareous cement. The red colouring of this succession is probably due to a high proportion of Permo-Triassic sandstone-derived material from the Irish Sea basin. This succession forms the entire cliff section in the middle of the bay but thins both to the northeast, where it forms the upper 
cliff at Penrhyn Bodeilas, and to the south-west, where it overlies the southern-central deposits described above. This succession appears to be infilling an erosional channel or large basin which has been eroded into the till and older deposits to the south-west (Figure 3).

\section{ENVIRONMENTS OF DEPOSITION}

The superficial deposits described are interpreted as being laid down by a waning ice sheet. The till at the base of the cliffs was deposited when Nefyn was covered by an ice sheet flowing southwards across the Irish Sea Basin.

As the ice front retreated northwards, the southern-central sedimentary succession (sands, gravels with silt bodies) was deposited in an ice-proximal (proglacial) environment. The lowest of these deposits has been interpreted as glacio-fluvial outwash, with aggrading channel fill deposits laid down in flowing water. The presence of silt-filled hollows within this succession indicates that, there were periods of quiescence, when standing water allowed the deposition of fine sediments. It is possible that these periods occurred when the ice front had retreated just offshore of the present coastline. The idea of a sustained presence of a nearby ice front is further supported by the presence of 'kettle hole' deposits exposed within the cliff section. These formed when blocks of ice fell from the degrading ice front and settled within the glacio-fluvial sediments. When these blocks of ice melted, they left voids into which other deposits could flow. The resultant voids have been filled with silts and fine sands.

Further research is being carried out to determine the depositional environment of deposits in the north-central region of the bay. However, the relatively homogenous nature of the sediments (sands and gravels), and absence of significant silt bodies associated with ice melt structures indicates a more distal glacio-fluvial environment when the ice sheet had retreated farther to the north.

The head deposits, found at the top of the cliff were formed by cold climate conditions following the retreat of the ice sheet, but before significant climatic warming had occurred. Fine grained, uniform deposits, with open structure and uniform texture were found at exposures at the cliff top in a number of locations along the bay. These have been interpreted as wind-blown deposits probably deposited in tundra-like conditions where exposed surface sediment can be easily mobilised by the wind.

\section{LATE PLEISTOCENE CLIMATE CHANGE AND EVOLUTION OF LANDSLIDE HAZARD}

\subsection{Glacial (>18,000 years BP)}

During the last (Devensian) glaciation, Nefyn Bay was covered by the Irish Sea Ice Sheet that extended southwards from the Irish Sea Basin, across the Lleyn Peninsula and out into Cardigan Bay (McCarroll, 2001). Deposition from this ice front has resulted in the lower, structureless lodgment till observed at Penrhyn Bodeilas in the north of the bay.

From about 18,000 years BP, the climate began to warm, and the Irish Sea Ice retreated in a northerly direction. This resulted in sediment being transported within the glacier being deposited as till. Although there is no direct evidence of surface landforms or mass-movement processes from this period, the exposed till surface was unstable and was able to mobilize and flow into hollows as a flow till. Deposition from this period has resulted in the upper till observed at Penrhyn Bodeilas. Overall, the result of this period was the emplacement of relatively strong, impermeable tills, which outcrop at either end of the bay.

\subsection{Proglacial (c.18,000 - c.14,000BP)}

As the ice front retreated, meltwater issuing from the front of the glacier deposited glacio-fluvial sand and gravels and there was periodic ponding of meltwater. In this highly active environment with abundant water and sediment supply it would be expected that any slopes present would be highly unstable and prone to movement. However, there is no visible evidence to suggest any such paraglacial landscape modification within this environment. The greatest impact from this climate was the deposition of a series of sands, gravels and silts in varying degrees of induration.

\subsection{Periglacial (c.14,000 - 12,000BP and 11,000 - $10,000 B P$}

As the Irish Sea ice sheet retreated from the Nefyn area, cold climatic conditions continued to persist across the region. Periglacial slope processes will have occurred during two distinct cold phases; at the end of the Devensian glaciation, and again for approximately 1000 years during a period termed the Loch Lomond Stadial.

Although there has been little research on the impact in North Wales of the relatively aggressive tundra-like climate, it is fair to assume that, as elsewhere (McCarroll et al., 2001), this period coincided with significant mass-movement activity. Such processes would have included shallow landsliding, 
deep landsliding, slope retreat and development of head within all of the sedimentary sequences,

Between these two periods of activity was the 1000 years or so of the Windermere Interstadial. The warm climate during this period generally resulted in less aggressive ground conditions and a reduction in mass-movement activity across Europe. It is likely that the region around Nefyn became vegetated at this time, further reducing the likelihood of mass movement processes.

\section{HOLOCENE CLIMATE CHANGE AND EVOLUTION OF LANDSLIDE HAZARD}

It is the climatic changes that have occurred during the Holocene, coupled with the legacy of the glacial and proglacial sedimentary environments that have influenced the style and mechanisms of landsliding in Nefyn Bay today. Several studies have utilized peat records and lacustrine oxygen isotope levels to model a climatic record for the Holocene around the Irish Sea Basin (see for instance Barber et al., 1994, Jones et al., 2002, Marshall et al., 2002, Barber et al., 2003). These demonstrate a significant warming at the end of the Loch Lomond Stadial (approximately 10,000 years ago), which, coupled with sea level rise, have been instrumental in the development of the landslide hazard. Even over the last 10,000 years, there have been wetter climatic conditions than those prevalent today (Fig. 4) and shortlived cold periods such as the "Little Ice Age" during the late $17^{\text {th }}$ and $18^{\text {th }}$ centuries AD.

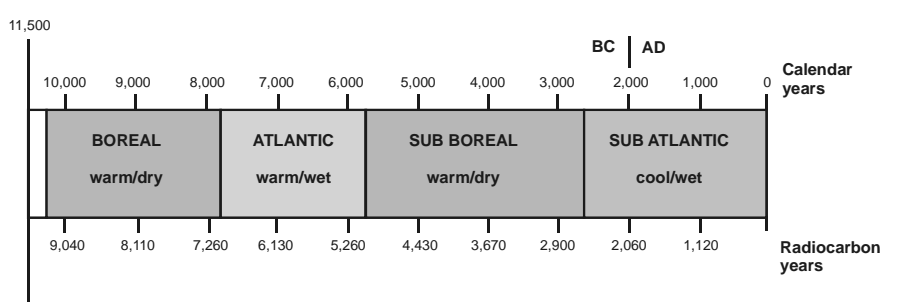

Figure 4. The climatic stages of the Holocene.

In the upper cliff in the area between the car park and Penrhyn Nefyn, a series of failures, now vegetated, can be observed. These have been interpreted as a series of degraded, non-circular, deep-seated rotational failures. Surface morphology suggests that sliding probably took place along shear zones within the laminated silt and massive clay units above the top of the indurated cobble gravel unit. It is thought that these were the result of the warm, wet climate during the warm Atlantic stage (Chiverell \& Innes, 2004). These conditions led to elevated pore-water pressures at impermeable boundaries -the top of the till or indurated beds within the pro-glacial sands and gravels. This situation led to the failure of the upper cliff resulting in a series of horizontal or backtilted benches upon which debris has subsequently accumulated. The significance of this is discussed below.

During the Holocene, sea level rose rapidly between 9000 - 7000 BP to approximately present day levels (Heyworth \& Kidson, 1982). During this period, the sequence of sediments seen at Nefyn was eroded, ultimately resulting in the creation of the modern day coastline.

\section{RECENT CLIMATE CHANGE AND EVOLUTION OF LANDSLIDE HAZARD}

Over the last 2000 years, the North Wales coast has experienced a relatively temperate climate. There may have a been a period of aggressive ground conditions during the Little Ice Age (McCarroll et al 2001), but there is no clear evidence of this within the survey area. This climate has led to the accumulation of a significant thickness $(0.5-10 \mathrm{~m})$ of organic rich debris. Generally the material forms a soft, saturated, deformable layer that typically builds up on the topographic benches formed over the large rotational landslides described above. Virtually the entire surface of the debris accumulation on the various benches seen in cliff profile was soft, wet and covered in tension cracks aligned perpendicular to the slope. Failures within this material were common, tending to occur in a shallow translational or rotational manner depending upon thickness, local hydrology and the gradient of the underlying slope. It was a failure in this surface material, following a heavy rainfall event, which resulted in the 2001 landslide.

Recent and contemporary sea level has resulted in the ongoing removal of material from the toe of the slopes (where undefended). This contributes both to the shallow failures observed at the base of the cliff and to the rockfall activity observed across the bay.

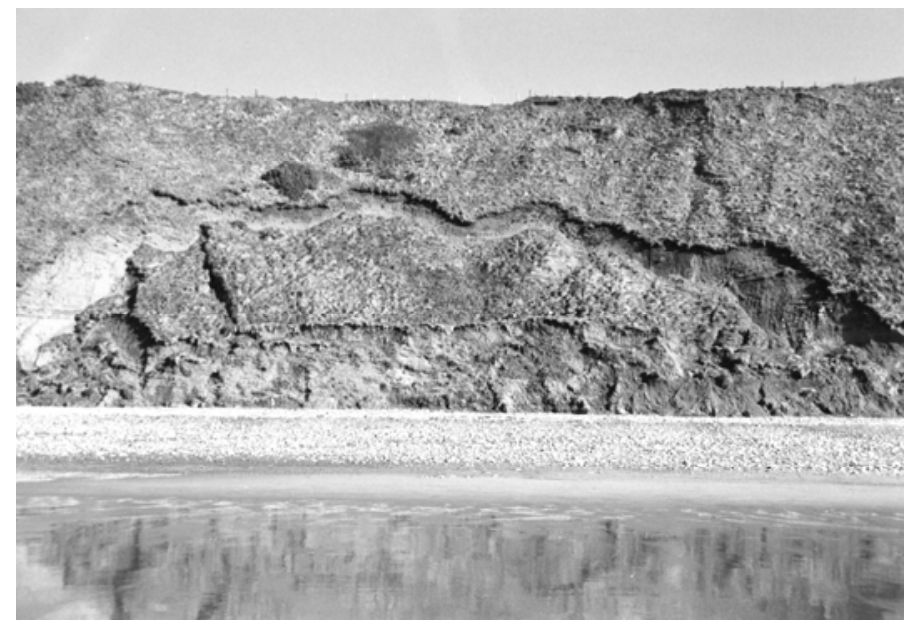

Figure 5. Planar slide at [230950 341150] in the glacio-fluvial sands and gravels. 
The relatively weak, permeable nature of sediments in the northern-central part of the bay, laid down in a proglacial environment, have formed steeply graded but vegetated slopes. Failures tend to be shallow planar slides (Fig. 5). One example, recorded in 2001, was over $60 \mathrm{~m}$ in width but involved a thickness of material no more than $2 \mathrm{~m}$. Elsewhere in the bay, failures observed within the glacio-fluvial sands and gravels were predominantly small slides and flows, generally less than $0.5 \mathrm{~m}$ deep and $1-2 \mathrm{~m}$ in length. Such failures are seen over the majority of the slope, often associated with small deposits at the base of the cliff that are removed at very high tides.

Failures were also associated with filled kettle holes. Figure 6 shows the largest of these, where recent erosion at the base of the cliff has led to a large mudflow. The failure occurred when part of the kettle basin was breached at its seaward side. The removal of lateral support for the sediments within the kettle basin, caused the fine-grained, cohesionless silt fill to fail rapidly and flow out through the breach leaving behind an empty flow bowl.

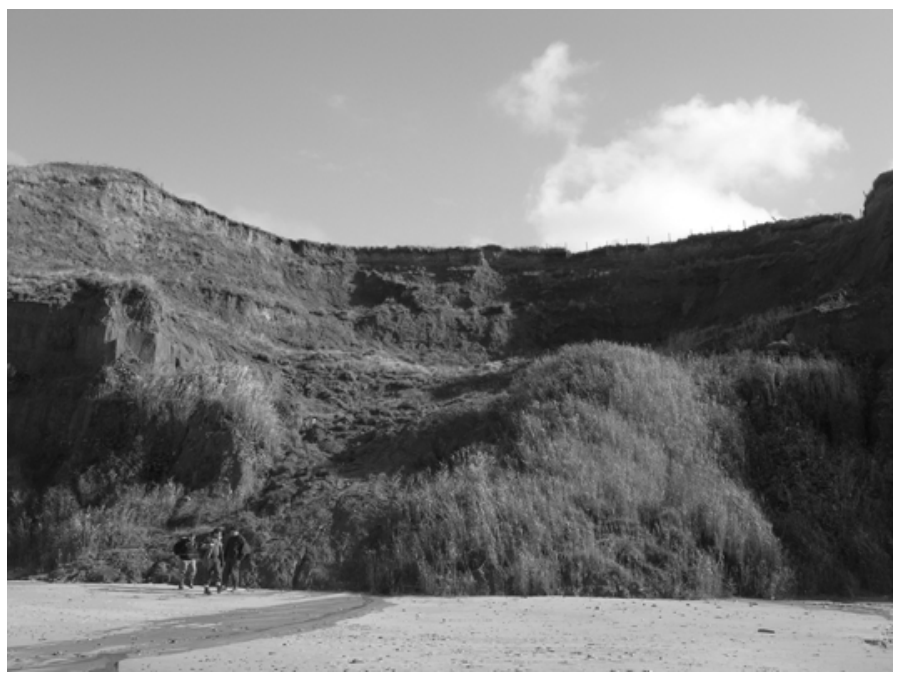

Figure 6. Kettle hole failure in silts at [230650 340955].

Rockfalls have resulted in the presence of a series of fallen blocks, usually of the indurated cobblegravel unit on the foreshore (Fig. 7). These blocks, some of which were 4-5 $\mathrm{m}$ in diameter, had fallen $10-15 \mathrm{~m}$ from the cliff, presumably when support was removed by coastal erosion of supporting sediments.

\section{LANDSLIDE HAZARD AND RISK}

The research undertaken by BGS in Nefyn Bay over the past five years was in response to the landslide that occurred in January 2001. The research has highlighted not only the hazards within the study area but also the need to consider the cumulative effects of different depositional and climatic environ- ments when building a picture of landslide hazard, especially where the post-glacial environment has been complex.

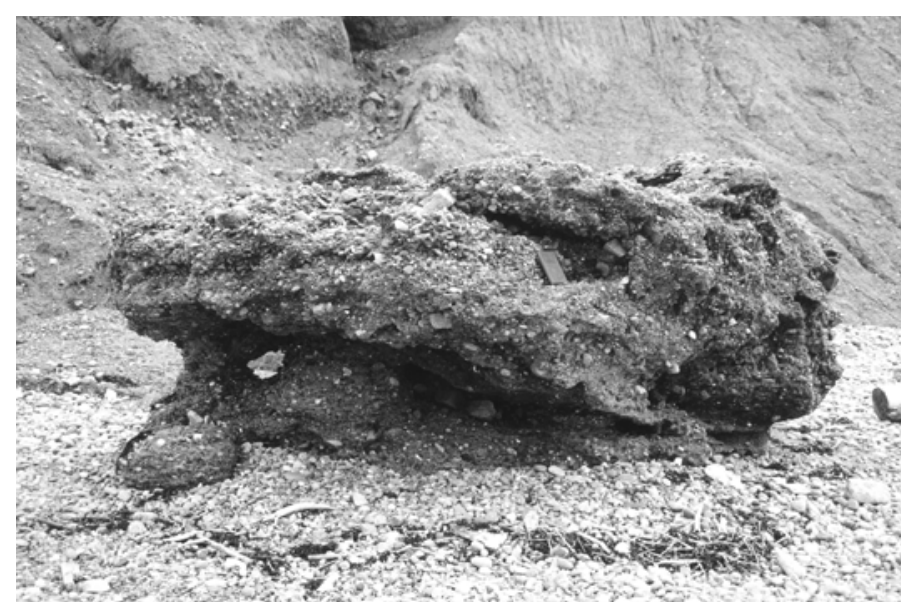

Figure 7. Fallen block of the indurated cobble gravel unit, indicative of a possible rockfall hazard below the cliffs.

Landslide hazards in Nefyn Bay and the risks resulting from them vary over very short distances. At present there is little hazard posed by rotational failures within the cliff. However, the presence of these degraded features has led to the generation of a separate hazard, that of a build up of weak, saturated debris, the behaviour of which is difficult to predict. It was a failure in this type of deposit that occurred in 2001, and this type of deposit remains the greatest hazard within the area today. The risk posed by most of these failures is, in most instances, low, as they will affect only a small area in the immediate vicinity of the failure. Risk is greatly increased when the area is transgressed by the built environment, for instance by the construction of chalets or access roads. Remediation work described by Statham (2002), has mitigated this risk immediately above the car park. However there are still adjacent areas of slope that have the potential to fail in the future, presenting a risk to both properties and life.

A coastal path traverses the top of the cliff, extending from Penrhyn Nefyn to the town of Nefyn before heading inland. Although the risk here of a landslide hazard coinciding with a walker being on the affected section of the path is relatively low, several tension cracks were observed along sections of the path during a visit in October 2006, so a considerable potential landslide hazard and risk is present.

A number of residential properties are located along the cliff top. With a forecast increase in more extreme climatic events, such as heavy rainstorms (DEFRA, 2006), a repeat of the heavy rainfall event such as that in 2001, coupled with continued coastal erosion at the toe of the cliff, presents a significant landslide risk in Nefyn Bay. 


\section{CONCLUSIONS}

Landslide hazard has evolved over time within Nefyn Bay, with this evolution linked intrinsically to long- and short-term climate change. The landslide hazard present today first began to evolve during the last (Devensian) Ice age as the Irish Sea Ice retreated from the northern Lleyn Peninsula and laid down a succession of glacial and proglacial deposits.

Coastal erosion associated with sea level rise has a significant control over slope mechanisms in Nefyn Bay. Failures resulting from coastal erosion vary widely, but include small scale falls of sand and gravel and larger slides in proglacial sediments, rockfalls from bedrock or till, and in some cases, rapid cliff failure due to the cutting of a kettle hole.

Relict non-circular rotational landslides that are stable today, but are presumed to have moved during a wetter climatic period during the Holocene, have indirectly caused the greatest landlside hazard today. These failures have provided a zone of subhorizontal benches upon which soft, unstable, organic rich debris has accumulated. Recent history has shown that these sediments can be mobilized during rapid onset events such as extreme rainfall episodes.

This research has highlighted that, especially in an area affected by proglacial deposition, the mechanisms, hazards and risk associated with landsliding can be very complex and can vary over short distances. Building such an understanding of slope evolution over time and with changing climate is a necessary step in understanding, and mitigating landslide hazard.

\section{REFERENCES}

Barber, K. E., Chambers, F. M. \& Maddy, D. 1994. A sensitive high-resolution record of Late Holocene climatic change from a raised bog in Northern England. The Holocene 4: 198-205.

Barber, K. E., Chambers, F. M. \& Maddy, D. 2003. Holocene palaeoclimates from peat stratigraphy; macrofossil proxy climate records from three oceanic raised bogs in England and Ireland. Quaternary Science Reviews 22(5-7): 521-539.

Chiverell, R. C. \& Innes, J. B. 2004. Holocene climate change, vegetation and environmental history. In R. C. Chiverell, A. J. Plater \& G. S. P. Thomas (eds), The Quaternary of the Isle of Man and North West England. QRA Field Guide.

DEFRA, 2006. Climate Change: The UK Programme 2006. The Stationery Office. London.

Gibson, A. D. \& Humpage, A. J. 2001a. The Geology and Cliff Stability at Nefyn, North Wales - Interim Report. British Geological Survey Commissioned Report CR/01/101, 32p.

Gibson, A. D. \& Humpage, A. J. 2001b. The Geology and Cliff Stability of Nefyn Bay, North Wales - Final Report. British Geological Survey Commissioned Report, CR/01/267.

Heyworth, A. \& Kidson, C. 1982. Sea-level changes in southwest England and Wales. Proceedings of the Geologists Association 93: 91-111.
Jones, R. T., Marshall, J. D., Crowley, S. F., Bedford, A., Richardson, N., Bloemendal, J. \& Oldfield, F. 2002. A high resolution, multi-proxy Lat-Glacial record of climate change and intrasystem responses in northwest England. Journal of Quaternary Science 17: 329-340.

Marshall, J. D., Jones, R. T., Crowley, S. F., Oldfield, F., Nash, S. \& Bedford, A. 2002. A high resolution Late-Glacial isotopic record from Hawes Water, Northwest England Climatic oscillations: calibration and comparison of palaeotemperature proxies. Palaeogeography, Palaeoclimatology, Palaeoecology 185: 25-40.

McCarroll, D. 2001. Deglaciation of the Irish Sea Basin: a critique of the glaciomarine hypothesis. Journal of Quaternary Science 16(5): 393-404.

McCarroll, D., Shakesby, R. A. and Matthews, J. A. 2001. Enhanced rockfall activity during the Little Ice Age; further lichenometric evidence from a Norwegian talus. Permafrost and Periglacial Processes 12(2): 157-164.

Statham, I. 2002. Failure on the coastal slope above Lon Gam, Nefyn, Llyn Peninsula: mechanism and remedial measures. In D. Nichol, M. G. Bassett \& V. K. Deisler (eds), Landslides and landslide management in North Wales, 99-105. National Museum of Wales Geological Series No. 22, Cardiff. 


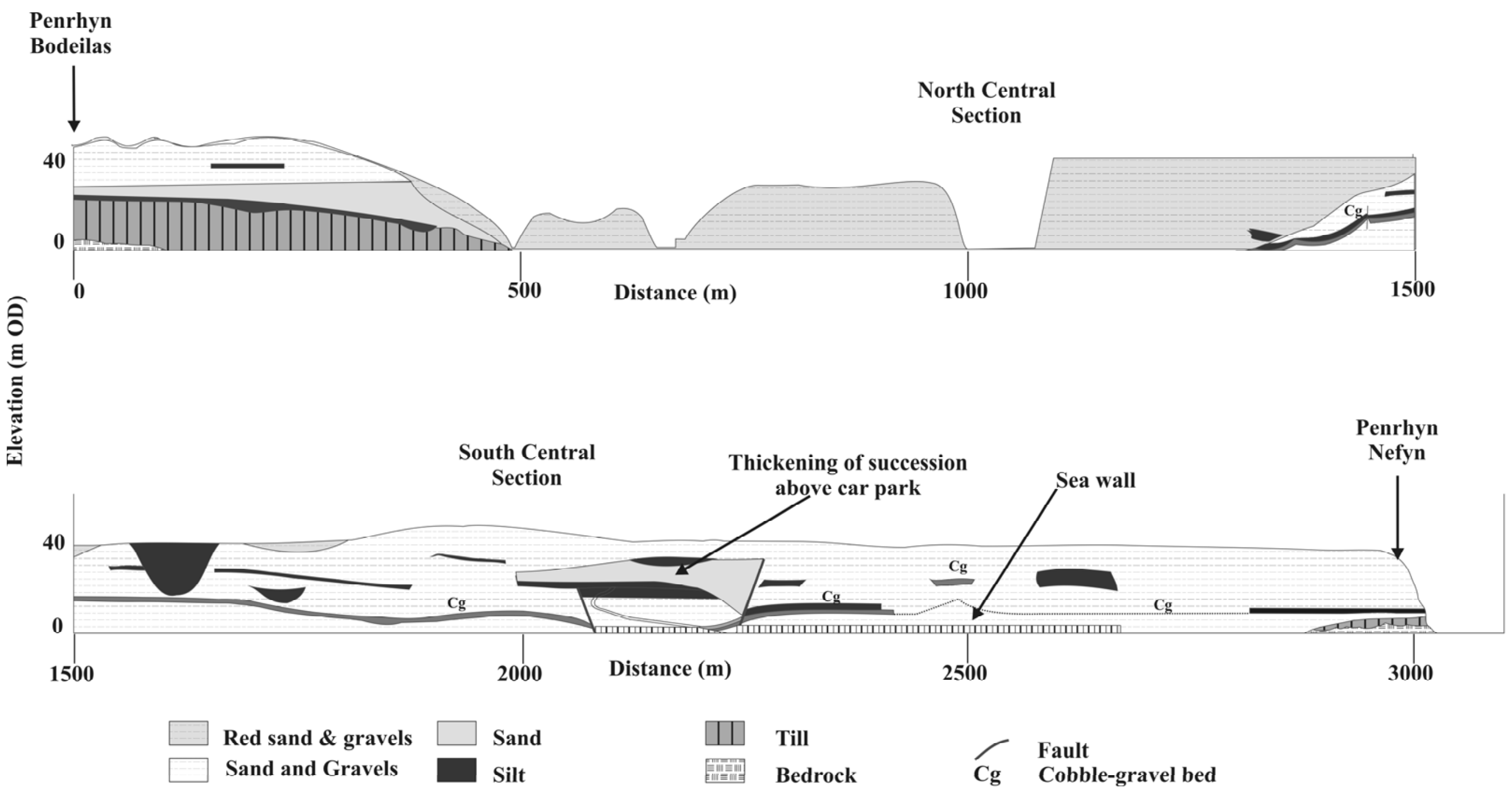

Figure 3. Geological cross section of the cliff section at Nefyn Bay. 